\title{
Evolution of Microstructure in Al-Si-Cu System Modified with a Transition Element Addition and its Effect on Hardness
}

\author{
Hansel Manuel Medrano-Prieto ${ }^{a}$, Carlos Gamaliel Garay-Reyes ${ }^{a}$, Cynthia Deisy Gómez-Esparza ${ }^{a}$, \\ Joaquín Aguilar-Santillán ${ }^{b}$, María Cristina Maldonado-Orozco ${ }^{a, c}$, Roberto Martínez-Sánchez ${ }^{a}$ \\ ${ }^{a}$ Laboratorio Nacional de Nanotecnología, Centro de Investigación en Materiales Avanzados - CIMAV, \\ Miguel de Cervantes No. 120, C.P. 31136, Chihuahua, Chihuahua, México \\ ${ }^{b}$ Materials and Tools LLC, 4118 E Washington Ct., Gilbert, AZ, USA. \\ ${ }^{c}$ Facultad de Ingeniería, Universidad Autónoma de Chihuahua-UACH, Circuito No. 1, Nuevo Campus \\ Universitario, Apdo. postal 1552, 31240, Chihuahua, Chihuahua, México
}

Received: November 5, 2015; Revised: June 14, 2016; Accepted: July 29, 2016

\begin{abstract}
The effect of Ni 1-2 wt.\% addition on the microstructure and hardness of the aged A319 alloy were studied. Characterization analyses by $\mathrm{x}$-ray diffraction, optical microscopy and scanning electron microscopy suggest clearly that $\mathrm{Ni}$ addition forms $\mathrm{Al}-\mathrm{Ni}-\mathrm{Cu}-\mathrm{Fe}, \mathrm{Al}-\mathrm{Cu}-\mathrm{Ni}$ and $\mathrm{Al}-\mathrm{Ni}$ intermetallic compounds that correlates well with equilibria conditions. Analyses by transmission electron microscopy show that aging heat treatment promotes microstructural changes in morphology, size, and spatial distribution of precipitates. Vickers micro-hardness test of $\mathrm{Ni} 1$ and $2 \mathrm{wt} \%$ specimens have a hardness increase from that of A319 alloy of $\sim 6-8 \%$ with mean values of 140.98 and $142.93 \mathrm{HV}$, respectively.
\end{abstract}

Keywords: Aluminum, A319 Alloy, Vickers micro-hardness, Heat Treatment, Precipitation hardening

\section{Introduction}

The aluminum alloys are commonly used in the automotive industry, from its excellent combination of strength and ductility ${ }^{1}$, moreover, of their high strength/weight ratio, corrosion resistance, excellent thermal conductivity and high cast ability allows the casting of complex forms ${ }^{2}$.

The A319 alloy, an Al-Si-Cu system, is commonly used in engine blocks and cylinder heads normally with a T6 heat treatment to improve mechanical properties. Kinetically, time and temperature, are two important variables to control during solution heat treatment (SHT) as they are responsible for $\mathrm{Si}$ modification and-dissolution of $\mathrm{Cu}$ and $\mathrm{Mg}$ enriched phases. The last is known as a diffusive process that strengthens the alloy matrix. During conventional SHT, the temperature must be kept below the melting point of the $\mathrm{Cu}$-rich phases in order to avoid incipient melting e.g. $\sim 500^{\circ} \mathrm{C}$. However, it should be high enough to create the optimum conditions for $\mathrm{Cu}$-rich phase dissolution and Si spheroidization. The standard T6 temper for A319 alloy consist in solution treatment for $8 \mathrm{~h}$ at $495^{\circ} \mathrm{C}$ and artificial aging at $155^{\circ} \mathrm{C}^{3-5}$.

The effects of heat treatments in $\mathrm{Al}-\mathrm{Si}-\mathrm{Cu}$ alloys have been studied by different techniques from different authors ${ }^{1,2,6,7}$. The authors reported that $\beta-\mathrm{Mg}_{2} \mathrm{Si}, \theta-\mathrm{Al}_{2} \mathrm{Cu}, \mathrm{Al}_{2} \mathrm{CuMg}$, and $\mathrm{Al}_{4} \mathrm{CuMg}_{5} \mathrm{Si}_{4}$ phases are dissolved during the SHT and are highly responsible of hardening of Al-Si-Cu-Mg, e.g. A319 type-alloys, after aging. In the case of A319 alloys different aging temperatures have been studied from 150 to $240{ }^{\circ} \mathrm{C}$. F.J. Tavitas Medrano et. al.,, , have reported a higher Vickers

*e-mail: roberto.martinez@cimav.edu.mx microhardness values and tensile strength at $170{ }^{\circ} \mathrm{C}$ compared to $155^{\circ} \mathrm{C}$ of the standard $\mathrm{T} 6$ temper.

In aluminum alloys, some transition metals like $\mathrm{Ni}$ and $\mathrm{Fe}$, and some rare earths like $\mathrm{Ce}$, which the main characteristic is their low solubility in Al e.g. maximum of $0.01 \%$ to $0.04 \%$, are employed in Al-Cu and Al-Si alloys to improve strength and hardness at elevated temperature. This is correlated mainly to impact its coefficient of thermal expansion ${ }^{8}$. Other authors have reported to enhance the mechanical properties from a formation of $\mathrm{Zr}-\mathrm{Ni}$ intermetallic in Al-Si-Cu-Mg alloys modified with small amounts of Ti$\mathrm{Zr}-\mathrm{Ni}^{9}{ }^{910}$. Hayajneh et. al., ${ }^{11}$ have studied the effect of $\mathrm{Ni}$ additions in the mechanical response in $\mathrm{Al}-\mathrm{Cu}$ system. They have reported $\mathrm{Al}_{3} \mathrm{Ni}, \mathrm{Al}_{3}(\mathrm{CuNi})_{2}$ and $\mathrm{Al}_{7} \mathrm{Cu}_{4} \mathrm{Ni}$ intermetallic compounds formations, which have a direct relationship with mechanical properties. Mohammad M. Hamasha et. al., ${ }^{12}$, have reported in Al-Cu-Ni alloys an increment in hardness as a function of $\mathrm{Cu}$ and $\mathrm{Ni}$ contents. In the same line of research, others investigations have reported $\mathrm{Al}_{9} \mathrm{FeNi}$ Intermetallic compound formation, which does not exhibit a 'Chinese script' or flake morphology like others Fe-phases, this also presents a relative high thermal stability ${ }^{13}$.

Because of the above described research, this work elaborates to undertake the effect of Ni additions in A319 alloy by hypothesizing that variation of microstructure and size of precipitates changes its Vickers micro-hardness. The results are presented and discussed as a function of $\mathrm{Ni}$ addition and different times in solution and aging heat treatments. 


\section{Experimental procedure}

The raw materials in present study were commercial A319 alloy and Al-20Ni (wt. \%) as a master alloy. The A319 alloy was melted in a Linderg Blue ${ }^{\mathrm{TM}}$ electric furnace at 740 ${ }^{\circ} \mathrm{C}$. The Al-20Ni master alloy was added into the melted A319 alloy in different proportions to obtain A319-1Ni (wt. \%) and A319-2Ni (wt. \%) alloys. Composition of the A319 alloys and A319 alloys modified with Ni additions are shown in Table 1. Thereafter, each alloy was degassed for 5 minutes with argon gas (20 psi), using a graphite propeller followed by a final $0.33 \mathrm{wt}$ \% of Al-5Ti-1B addition as a grain refiner. The alloys were casted into preheated steel molds $(\Phi=2 \mathrm{~cm}, \mathrm{~h}=10 \mathrm{~cm})$ at $260{ }^{\circ} \mathrm{C}$. Subsequently, heat treatment (SHT) were done at $495{ }^{\circ} \mathrm{C}$ during 5 and 7 $\mathrm{h}$ in a Linderg Blue ${ }^{\mathrm{TM}}$ electric furnace with a heating rate of $50{ }^{\circ} \mathrm{C} / \mathrm{min}$ followed by a quenching in water at $60^{\circ} \mathrm{C}$. Aging heat treatments were done in a Felisa ${ }^{\mathrm{TM}}$ furnace at $170^{\circ} \mathrm{C}$ for different period of time $(0.5,4,6,10$ and 96 $\mathrm{h}$ ), followed by quenching in water at room temperature. The microstructure of samples after heat treatments was characterized by $\mathrm{x}$-ray diffraction (XRD), scanning electron microscopy (SEM) and transmission electron microscopy (TEM). XRD analyses were performed in a Panalytical X'Pert PRO diffractometer at conditions of $40 \mathrm{kV}$ and 35 $\mathrm{mA}$ with $\mathrm{Cu} \mathrm{K} \alpha$ radiation of $\lambda=0.15406 \mathrm{~nm}$. Analyses by SEM were carried out in a Jeol ${ }^{\text {TM }} 5800$ LV operated at $20 \mathrm{kV}$. SEM samples were prepared by conventional metallography techniques. TEM observations were carried out in a Jeol ${ }^{\mathrm{TM}} \mathrm{JEM} 2200 \mathrm{~F}+\mathrm{CS}$ operated at $200 \mathrm{kV}$. TEM samples were prepared by electropolishing procedure in a Struers ${ }^{\mathrm{TM}}$ tenupol 5 using a mixture $\mathrm{MeOH}: \mathrm{HNO}_{3}$, with a ratio 80:20 in volume at $-50{ }^{\circ} \mathrm{C}$. The electron diffraction patterns were obtained by nano beam diffraction technique (NBD) with a probe size about $40 \mathrm{~nm}$. Vickers microhardness tests were done in a Future Tech ${ }^{\mathrm{TM}}$ FM-7 Microhardness Tester. Polished surfaces, $100 \mathrm{~g}$ of load and $15 \mathrm{~s}$ of dwell time were the conditions for this test. The average of 10 indentations is reported.

\section{Results and Discussion}

\subsection{Optical Microscopy (OM)}

A representative micrograph of the microstructure of A319 alloy as cast condition is illustrated in Figure 1a. This is named as reference sample in the present study. The microstructure consists primarily of a dendritic morphology with dendritic $\alpha-\mathrm{Al}$ arms, Si-rich platelets, $\mathrm{Al}-\mathrm{Cu}$ phases and Fe-containing intermetallic compounds. The Ni addition in Al-based alloys forms Al-Ni intermetallic compounds, which show high thermal stability and improve its mechanical properties at elevated temperatures. The Figures $1 \mathrm{~b}$ and 1c illustrate the as-cast condition microstructure of A319 alloy modified with Ni additions of 1 and 2 wt. $\%$, respectively. In these illustrations, the presence of platelets-like Al-Ni intermetallic compounds and reduction in size of dendrites respect to reference sample are clearly observed. The process of $\mathrm{Ni}$ addition suggests Al-Ni intermetallic compounds formations act as potential sites of heterogeneous nucleation that lead to a microstructure refinement.

\subsection{Scanning Electron Microscopy (SEM)}

The microstructures of the A319 alloy modified with 1 wt. $\% \mathrm{Ni}$ and solubilized for 5 and $7 \mathrm{~h}$, are showed in Figures 2 and 3, respectively. Spatial distribution obtained by energy dispersive spectroscopy (EDS) mapping elements e.g. Al, Si, Cu, Fe, Mn and Ni and chemical composition of principal phases are also included. These figures illustrate the presence of Si-rich and Al-Fe-Mn-Si phases with rounded and elongated needles morphologies. Spheroidization and diminution in aspect ratio of Si-rich phases during SHT are observed. This results in a loss of interconnectivity of the eutectic phases ${ }^{14,15}$. Figure 2 illustrates Al-Cu-Ni phases with Chinese script type morphologies. The formations of these intermetallic compounds are expected in $\mathrm{Al}-\mathrm{Ni}-\mathrm{Cu}$ alloys and greatly reduce $\mathrm{Cu}$ content available in Al-matrix for its precipitation and consecutive hardening ${ }^{16,17}$. Figure 3 illustrates the dissolution of Al-Cu-Ni phases with Chinese script type morphology, $\mathrm{Cu}$ content in those phases is expected that decrease from that longer solution times $\sim 7$ $\mathrm{h}$ favor higher $\mathrm{Cu}$ dissolution.

The microstructure of the A319 alloy with Ni 2 wt. $\%$ after SHT at $495{ }^{\circ} \mathrm{C}$ for $5 \mathrm{~h}$ is presented in Figure 4. It is observed an increment of the $\mathrm{Ni}$ in modified alloys which affects volume-fraction and chemical composition of the Ni-containing phase. In addition, there is no evidence of $\mathrm{Al}-\mathrm{Cu}-\mathrm{Ni}$ phases with Chinese script type morphology, only Al-Ni-Cu-Fe phases with plate-type morphology. The above is expected from a higher $\mathrm{Ni}$ content stabilizes the Ni-containing phases. In the other aspect of analysis, the volume-fraction and morphology of eutectic Si is independent of the Ni concentration as previously reported by ${ }^{14}$.

Table 1: Chemical compositions of the A319 alloy and A319 alloys modified with Ni additions. (wt. \%).

\begin{tabular}{|c|c|c|c|c|c|c|c|c|c|c|c|}
\hline Alloy & $\mathrm{Si}$ & $\mathrm{Cu}$ & $\mathrm{Mg}$ & $\mathrm{Mn}$ & $\mathrm{Fe}$ & $\mathrm{Ni}$ & $\mathrm{Zn}$ & $\mathrm{Cr}$ & $\mathrm{Ti}$ & $\mathrm{Sr}$ & $\mathrm{Al}$ \\
\hline A319 & 8.32 & 2.80 & 0.50 & 0.55 & 0.77 & 0.02 & 0.41 & 0.33 & 0.14 & 0.01 & Bal \\
\hline $\mathrm{A} 319+1 \mathrm{Ni}$ & 7.79 & 2.97 & 0.50 & 0.44 & 0.67 & 1.12 & 0.41 & 0.3 & 0.13 & 0.00 & Bal \\
\hline $\mathrm{A} 319+2 \mathrm{Ni}$ & 7.75 & 2.82 & 0.43 & 0.37 & 0.58 & 2.03 & 0.38 & 0.03 & 0.10 & 0.00 & Bal \\
\hline
\end{tabular}



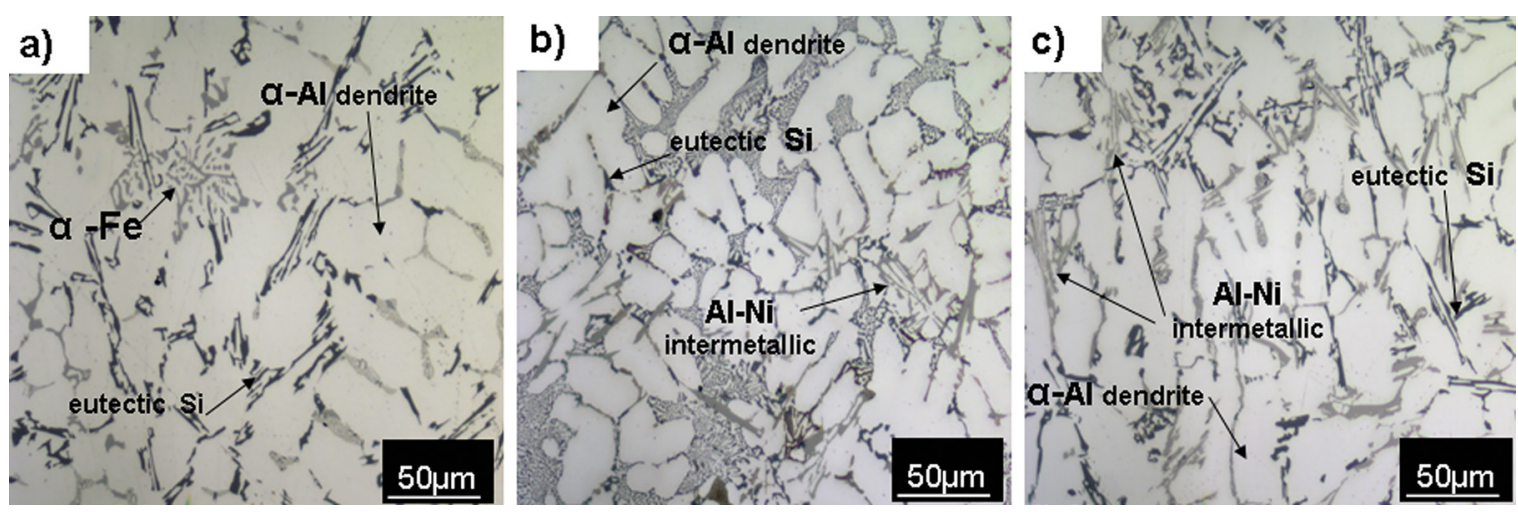

Figure 1: OM micrographs of : a) A319 alloy b) and c) A319 alloy modified with 1 and 2Ni (wt. \%), respectively, in as cast condition.

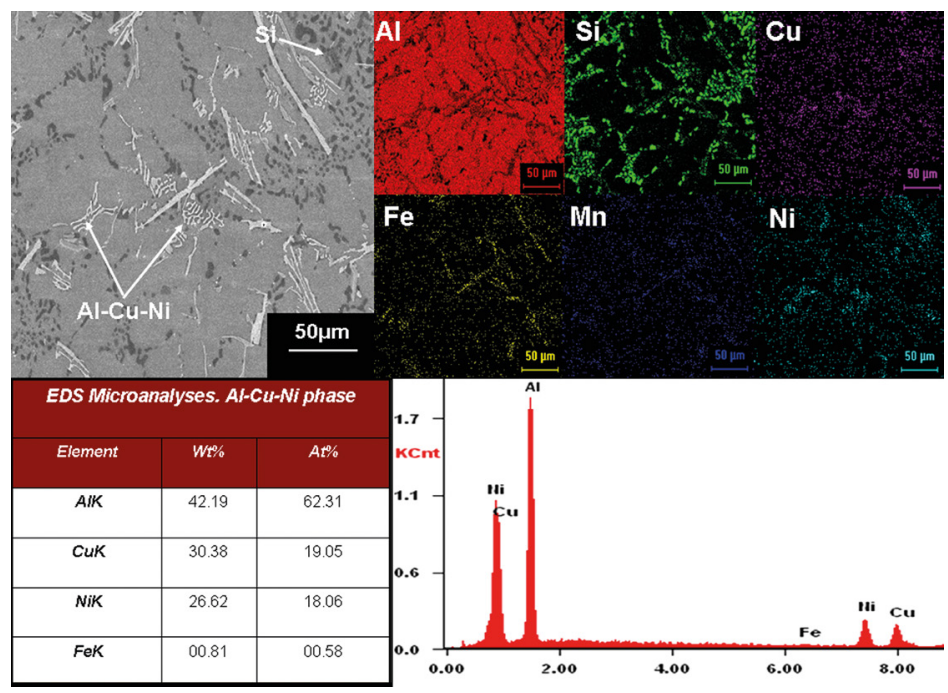

Figure 2: SEM micrograph, EDS mapping and measurement of chemical composition corresponding to phases of the A319 alloy modified with $1 \mathrm{Ni}$ (wt. \%) after SHT for $5 \mathrm{~h}$.

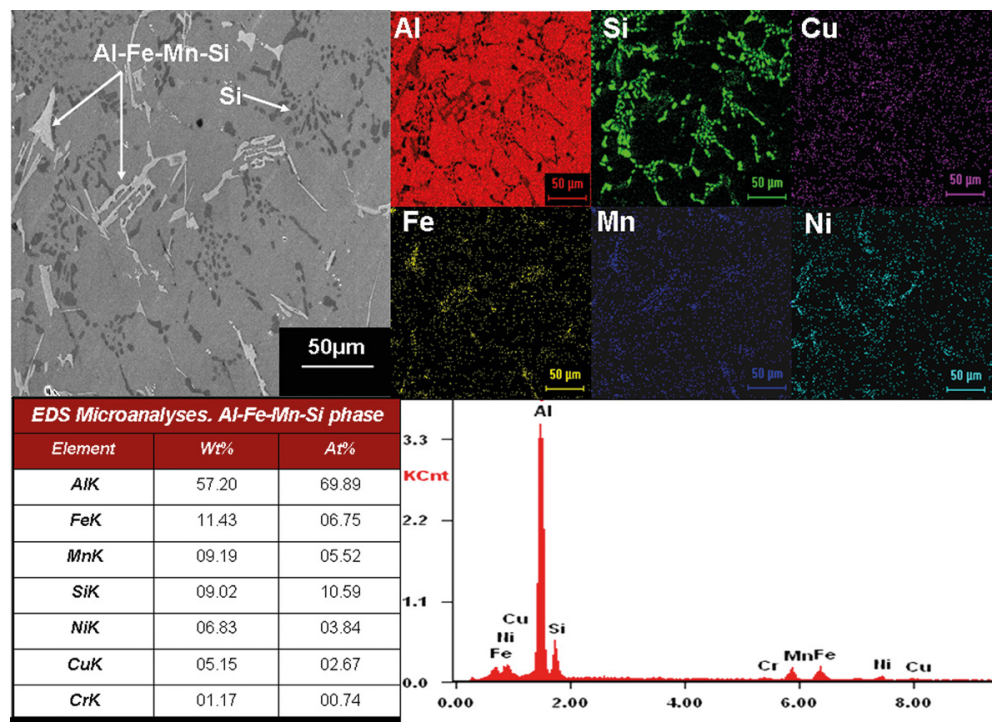

Figure 3: SEM micrograph, EDS mapping and measurement of chemical composition corresponding to phases of the A319 alloy modified with $1 \mathrm{Ni}$ (wt. \%) after SHT for $7 \mathrm{~h}$. 


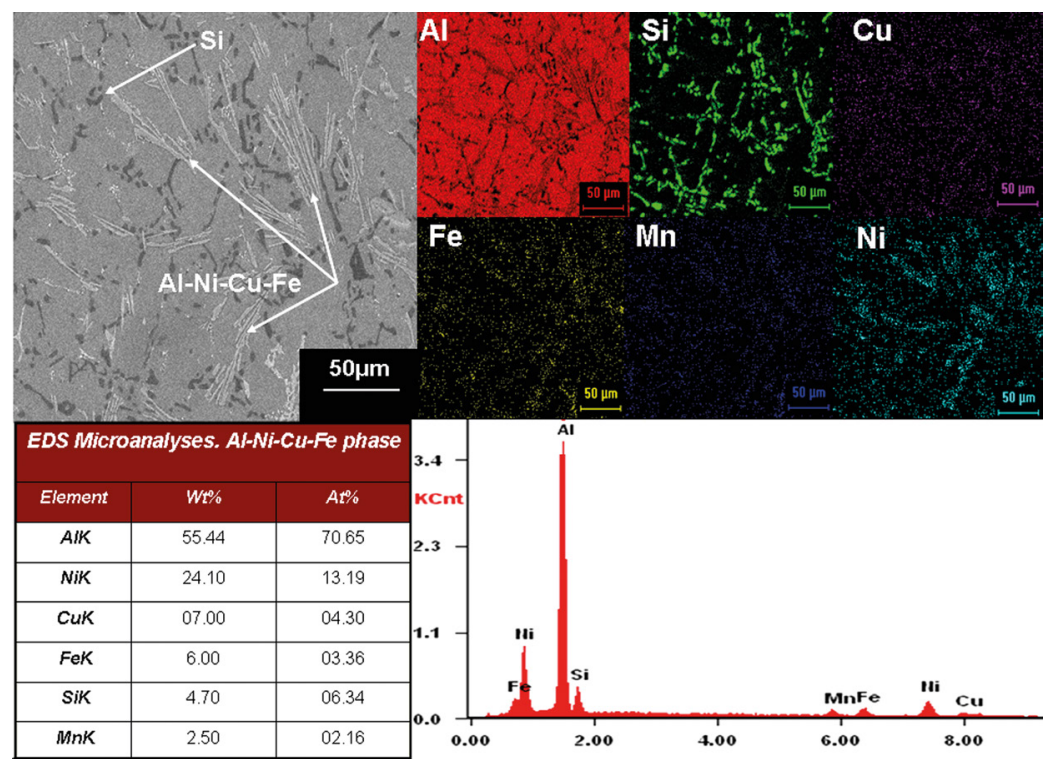

Figure 4: SEM micrograph, EDS mapping and measurement of chemical composition corresponding to phases of the A319 alloy modified with $2 \mathrm{Ni}$ (wt. \%) after SHT for $5 \mathrm{~h}$.

\subsection{X-Ray Diffraction (XRD)}

Reference sample XRD analyses and those modified with $\mathrm{Ni}$ additions were carried out mainly to identify crystalline phases and presence of compounds in two fold: (a) as-cast condition and (b) after SHT at $495{ }^{\circ} \mathrm{C}$ for $7 \mathrm{~h}$. Figure 5 illustrates the XRD patterns. In reference sample as-cast condition are observed phases corresponding to $\mathrm{Al}$ and $\mathrm{Si}$. The characteristics $\mathrm{Cu}$ rich phases $\left(\mathrm{Al}_{2} \mathrm{Cu}\right.$ and $\left.\mathrm{Al}_{2} \mathrm{CuMg}\right)$ and those thermally stables containing $\mathrm{Fe}\left(\mathrm{Al}_{8} \mathrm{FeMg}_{3} \mathrm{Si}_{6}\right.$ and $\mathrm{AlFeSi}$ ) are easily identified. However, after SHT dissolution of phases containing $\mathrm{Cu},\left(\mathrm{Al}_{2} \mathrm{Cu}\right.$ and $\left.\mathrm{Al}_{2} \mathrm{CuMg}\right)$ are observed. Samuel et. al., ${ }^{18}$ have reported the dissolution of $75 \%$ of $\theta-\mathrm{Al}_{2} \mathrm{Cu}$ phase after SHT at $515^{\circ} \mathrm{C}$ for $8 \mathrm{~h}$. Recent investigation ${ }^{19}$ in $\mathrm{Al}-\mathrm{Si}-\mathrm{Cu}-\mathrm{Mg}$ alloy have reported partial dissolution of $\theta-\mathrm{Al}_{2} \mathrm{Cu}$ phase in a range of 300 to $500{ }^{\circ} \mathrm{C}$. These are in agreement with results reported in Figure 5. It is identified in A319 alloy modified with Ni after SHT phases with $\mathrm{Al}, \mathrm{Ni}$ and $\mathrm{Fe}$ content and dissolution of $\mathrm{Cu}$ rich phases. These results conclusively confirm that phases containing $\mathrm{Ni}$ (others reported $\mathrm{Fe}$ ) present a high thermal stability and remain present after $\mathrm{SHT}^{17}$.

\subsection{Vickers Micro-hardness (HV)}

The resulting improvement of the mechanical properties after T6 heat treatment is directly correlated to the interdendritic $\mathrm{Si}$ and the precipitation hardening as previously reported $\mathrm{d}^{4,20,21}$. The eutectic $\mathrm{Si}$ is spheroidizing in shape and reduces its size during solution heat treatment.
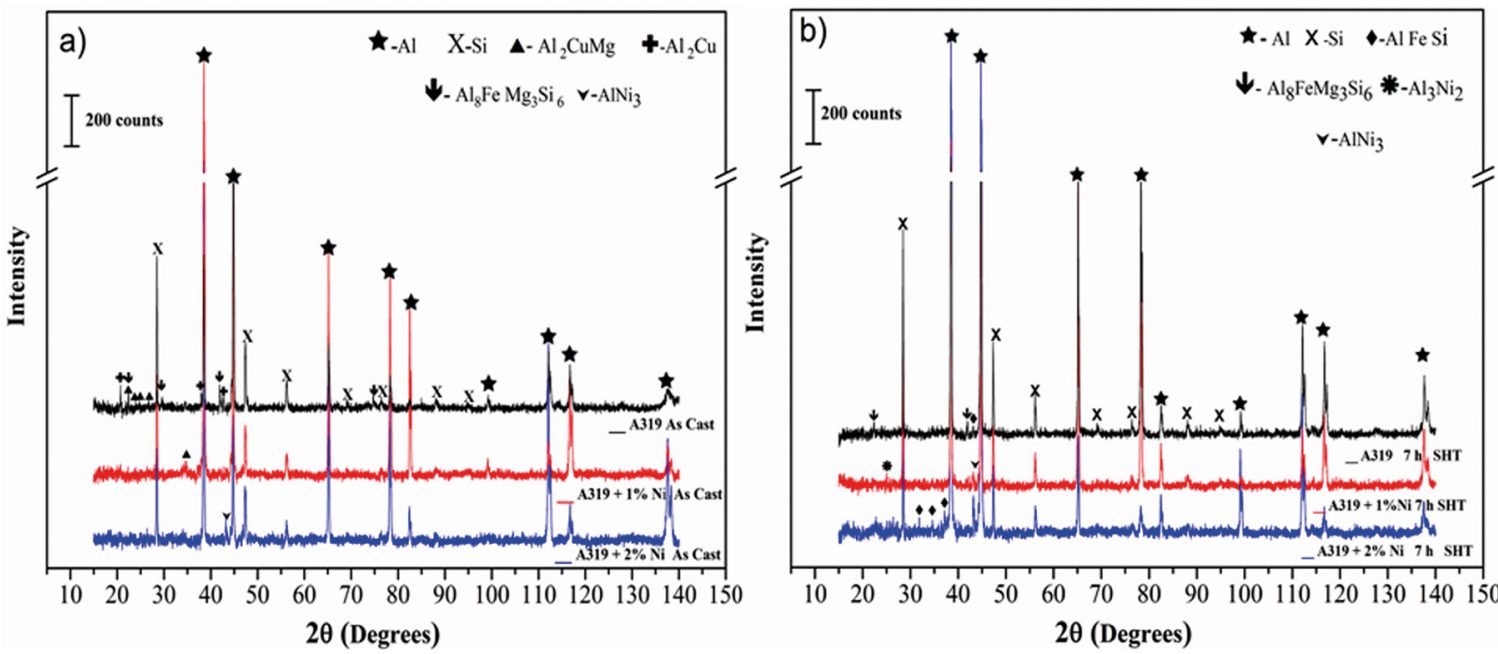

Figure 5: XRD patterns obtained in A319 alloy with and without Ni additions a) as cast condition and b) after SHT at $495{ }^{\circ} \mathrm{C}$ for $7 \mathrm{~h}$. 
The aluminum matrix is over saturated with $\mathrm{Cu}$ and Mg. After SHT, the precipitation mechanism is directly correlated to the strengthening process ${ }^{4,9,21}$. Vickers microhardness (HV) tests were undertaken to evaluate the effect of precipitation hardening and $\mathrm{Ni}$ addition in aluminum matrix. Figure 6 illustrated the measured $\mathrm{HV}$ values as a function aging time in reference sample and those modified with $\mathrm{Ni}$ additions. The slope ( $\mathrm{dHv} / \mathrm{dt}$ ) shows an increment in hardness values as a function of aging time reaching a maximum value and follows a slope reduction suggesting a mechanical response reduction. The HV values in alloys modified with $\mathrm{Ni}$ additions are higher than those found in reference sample. For A319 alloy, a maximum value of $133.15 \mathrm{HV}$ has been obtained in samples aged for 360 $\min (6 \mathrm{~h})$, similar to the value of $134 \mathrm{HV}$ has reported by Tavitas-Medrano et al. ${ }^{5}$ for A319 alloy modified with (Mg and $\mathrm{Sr}$ ). For the $\mathrm{A} 319$ alloys with Ni additions, maximum values of 140.98 and $142.93 \mathrm{HV}$ have been obtained in samples aged $360 \mathrm{~min}(6 \mathrm{~h})$ and $240 \mathrm{~min}(4 \mathrm{~h})$ for Ni 1 and 2 wt. $\%$, respectively.

Several authors ${ }^{1,7}$ suggest that $\theta^{\prime \prime}, \theta^{\prime}-\mathrm{Al}_{2} \mathrm{Cu}$ and $\beta^{\prime}-\mathrm{Mg}_{2} \mathrm{Si}$ (coherent and Semi-coherent) metastable phases are the main responsible for the increment in hardness, and $\theta-\mathrm{Al}_{2} \mathrm{Cu}$ $\beta-\mathrm{Mg}_{2} \mathrm{Si}$ (Incoherent) and stable phases are responsible for the decrement. It is observed that increasing the Ni content in the A319 alloy increases HV values and peak of hardness appears at shorter aging time. Additionally, in samples modified with $\mathrm{Ni}$ additions the hardness values decreases slowly during overaging condition. This means that $\mathrm{Ni}$ additions slow down the coarsening kinetics of $\theta-\mathrm{Al}_{2} \mathrm{Cu}$ phase which agrees with reported by Hayajneh et. al., ${ }^{11}$. However, other studies ${ }^{9,14}$ have reported that the addition up to $\mathrm{Ni} 1.41 \mathrm{wt}$ \% decreases the hardness and tensile properties from less available $\mathrm{Cu}$ to form $\theta^{\prime \prime}$ and $\theta^{\prime}-\mathrm{Al}_{2} \mathrm{Cu}$ phase during aging treatment.

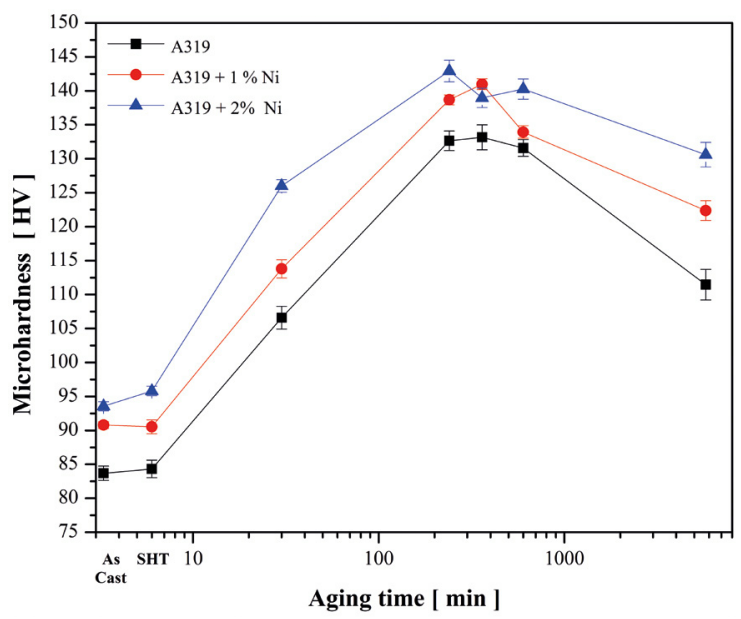

Figure 6: Vickers microhardness as a function of aging time for the A319 alloy and those modified with $\mathrm{Ni}$ additions, the samples were SHT at $495^{\circ} \mathrm{C}$ for $7 \mathrm{~h}$ and aged at $170{ }^{\circ} \mathrm{C}$ for different times.

\subsection{Transmission Electron Microscopy (TEM)}

Characteristics of precipitated phases and its interfacial microstructural development have direct correlation to its mechanical properties. TEM illustrates a direct relationship to understand the $\mathrm{Ni}$ effect on its mechanical behavior for the samples studied in this work. The Figure 7a illustrates the main microstructural characteristics of precipitated phases and the indexed TEM-NBD pattern in reference sample after T6 heat treatment. The STEM-Brigth-Field (BF) micrograph illustrates precipitates with noodles-like morphology, thickness of 2 to $5 \mathrm{~nm}$ and length between 30 to $100 \mathrm{~nm}$. This morphology is typical of $\theta^{\prime}-\mathrm{Al}_{2} \mathrm{Cu}$ precipitates. In the TEM-NBD pattern obtained along to the [110] zone axis different kinds of spots are observed, those with higher intensity correspond to aluminum matrix and $\theta^{\prime}-\mathrm{Al}_{2} \mathrm{Cu}$ phase, along theses spots, it is observed the presence of streaks, which are generated for Guinier-Preston (GP) zones ${ }^{22,23}$. Furthermore, the presence of diffuse satellites around the principal spots have been reported in aged $\mathrm{Al}-\mathrm{Cu}$ alloys from spinodal decomposition ${ }^{22,24,25}$. The Figure 7c illustrates a close up of these precipitates which have been reported partially coherent and metastable phases with body-centered tetragonal crystal structure. The lattice parameters are $\mathrm{a}=\mathrm{b}=0.406 \mathrm{~nm}$, $\mathrm{c}=0.58 \mathrm{~nm}$ and space group $I 4 / \mathrm{mcm}^{2,24,26,27}$. The Figure $7 \mathrm{~b}$ illustrates EDS elemental microanalyses of aluminum matrix and acicular precipitates and confirms the presence of $\mathrm{Cu}$ and $\mathrm{Al}$ in these precipitated phases.

The Figure 8 illustrates STEM-BF micrographs of A319 alloy modified with Ni 1 and $2 \mathrm{wt}$ \% after SHT for $7 \mathrm{~h}$ and aged for $10 \mathrm{~h}$. Figures $8 \mathrm{a}$-b illustrate the precipitates $\left(\mathrm{Al}_{2} \mathrm{Cu}\right)$ as well as the corresponding indexation of TEM-NBD patterns. The size of precipitates in this alloys are smaller than those presented in reference alloy. The thickness and length of these precipitates are around 0.6-1.5 nm and 9-28 $\mathrm{nm}$ respectively, and a higher number density of precipitates is clearly observed. The TEM-NBD patterns obtained along to the [110] zone axis show the principals reflections corresponding to the $\alpha-\mathrm{Al}$ matrix. Streaks and the diffuse satellites were observed in the diffraction pattern of the Figure $8 \mathrm{~b}$ which are attributed to the presence of GP zones and spinodal decomposition. The HRSTEM micrograph (Figure $8 \mathrm{c}$ ) shows one of the full coherent precipitates present in the microstructure of the modified alloy $2 \mathrm{Ni}$ (wt. \%), which is formed by 4-6 atomic layers. These precipitates phases could correspond to GP-II zones or $\theta$ "'- $\mathrm{Al}_{2} \mathrm{Cu}$. It has been previously reported as coherent and formed approximately by 5 atomic layers in thickness ${ }^{28}$. The results presented in the hardness graphs of Figure 6, as well as the observations obtained by STEM in this investigation, are correlated with the results presented by Wiengmoon et. al., ${ }^{26}$. This author reported in A319 alloy that the hardness peak in aged condition is obtained in the presence of a higher number density of $\theta$ " and a lower number density of $\theta^{\prime}$. In addition, Sjolander 

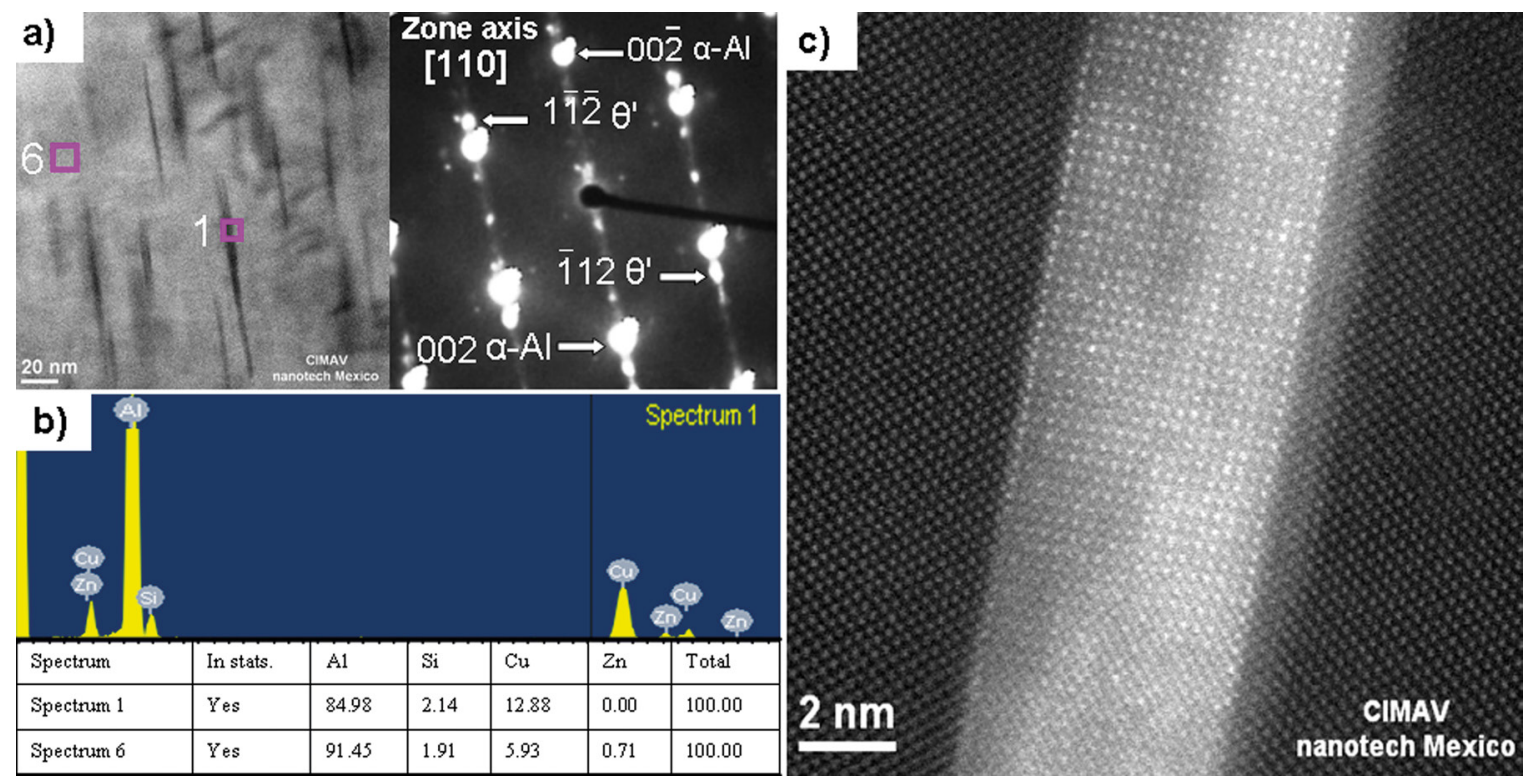

Figure 7: a) Bright field (BF) STEM micrograph of reference alloy and NBD pattern, b) EDS elemental microanalyses of $\mathrm{Al}_{2} \mathrm{Cu}$ precipitates and c) Z-contrast $\mathrm{HRSTEM}$ micrograph of $\theta^{\prime}-\mathrm{Al}_{2} \mathrm{Cu}$ precipitate after aging at $170{ }^{\circ} \mathrm{C}$ for $10 \mathrm{~h}$.
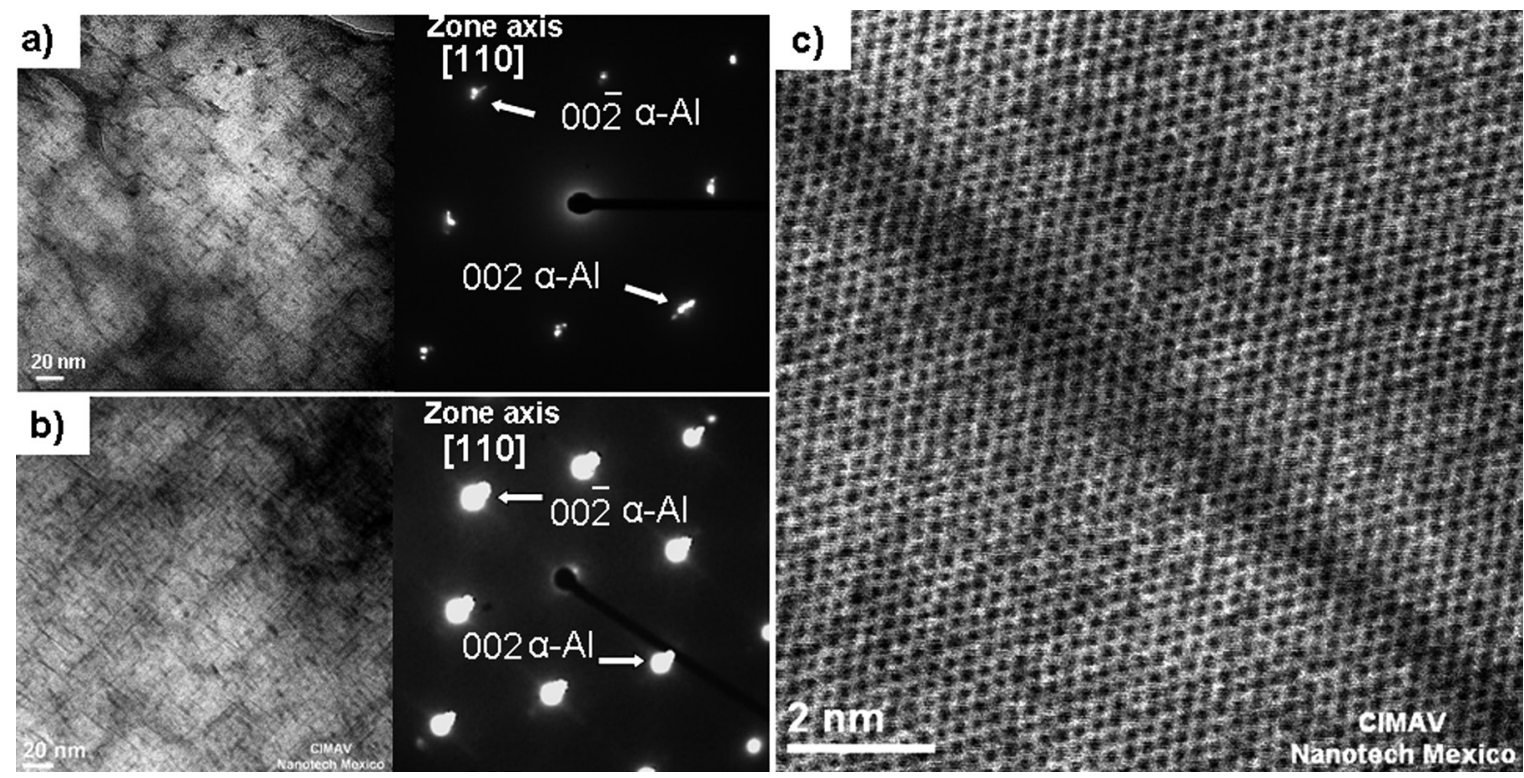

Figure 8: a) and b) Bright field (BF) STEM micrographs and NBD patterns of alloys modified with 1-2Ni (wt. \%) respectively, c) Bright field (BF) HRSTEM micrograph of full coherent precipitate in alloy modified with $2 \mathrm{Ni}$ (wt. \%) after aging at $170{ }^{\circ} \mathrm{C}$ for $10 \mathrm{~h}$.

et. al., ${ }^{2}$ reports that the higher strength is obtained when a higher fraction of $\theta$ " is present.

The differences in size and number density of precipitates phases between the reference alloys and those modified could be attributed to the Ni addition. The SHT time is an important variable in the process. The longer solution times contributes to a higher dissolution of $\mathrm{Cu}$ phases and improve the precipitation of $\theta^{\prime \prime}$ and $\theta^{\prime}-\mathrm{Al}_{2} \mathrm{Cu}$ during aging step. However, because of $\mathrm{Ni}$ additions, the precipitation sequence and kinetic were modified. This last step resulting in a high number density of precipitates with smaller size. The effect of this step in precipitation sequence is observed in the hardness graph (Figure 6). This shows a direct effect in the strengthening behavior. Alloys modified with $\mathrm{Ni}$ additions show higher hardness values than the reference alloy. Additionally, in this figure a delay on precipitation kinetic is observed, being more evident in the overaging step. Another significant effect of $\mathrm{Ni}$ addition is the slow hardness process gains during overaging condition. This effect is attributed to difference in size of $\theta-\mathrm{Al}_{2} \mathrm{Cu}$ precipitates phases in the reference alloy and the alloys modified with $\mathrm{Ni}$ additions in equal aging times. 


\section{Conclusions}

The effects of $\mathrm{Ni}$ additions and heat treatments on the microstructure, hardness and aging kinetics to the A319 aluminum alloy were investigated. The following results were obtained.

1. The Ni additions of 1 and 2 wt. $\%$ to the A 319 alloy favored the formation of intermetallic compounds containing $\mathrm{Ni}$ (Al-Ni-Cu-Fe, Al-Cu-Ni and Al-Ni). Furthermore, changes in morphology, distribution, type, size and number density of the $\mathrm{Al}_{2} \mathrm{Cu}$ precipitates formed during aging heat treatment were observed

2. TEM analyses in the reference alloy showed a higher number density of semicoherent $\theta^{\prime}-\mathrm{Al}_{2} \mathrm{Cu}$ precipitates. By the other hand, in the microstructure of A319 alloy modified with $\mathrm{Ni}$ addition of 1 and 2 wt. \% a higher number density of small and full coherent precipitates was observed

3. Increase of hardness values between $\sim 6-8 \%$ in samples modify with $\mathrm{Ni}$ additions was obtained.

4. In samples modify with Ni additions a slow coarsening kinetics of $\theta^{\prime}-\mathrm{Al}_{2} \mathrm{Cu}$ was observed, mainly in the overaging condition.

\section{Acknowledgements}

The technical assistance of Karla Campos Venegas for SEM characterization, Raul Ochoa Gamboa, Javier Camarillo Cisneros and Carlos Ornelas for TEM characterizations greatly appreciated. The first author would like to thank CONACYT for the scholarship.

\section{References}

1. Tash M, Samuel FH, Mucciardi F, Doty HW. Effect of metallurgical parameters on the hardness and microstructural characterization of as-cast and heat-treated 356 and 319 aluminum alloys. Materials Science and Engineering. 2007; 443: 185-201

2. Sjölander E, Seifeddine $\mathrm{S}$. The heat treatment of $\mathrm{Al}-\mathrm{Si}-\mathrm{Cu}-\mathrm{Mg}$ casting alloys. Journal of Materials Processing Technology 2010;210(10):1249-1259.

3. Gauthier J, Louchez PR, Samuel FH. Heat treatment of 319.2 aluminum automotive alloy, Part 1 , Solution heat treatment. Cast Metals. 1995;8(2):91.

4. Sokolowski JH, Sun XC, Byczynski G, Northwood DO, Penrod DE, Thomas R, et al. The removal of cooper-phase segregation and the subsequent improvement in the mechanical properties of cast 319 aluminum alloys by a two-stage heat treatment. Journal of Advanced Materials Processing Technology. 1995;53(1-2):385-392.

5. Tavitas-Medrano FJ, Gruzleski JE, Samuel FH, Valtierra S, Doty HW. Effect of Mg and Sr-modification on the mechanical properties of 319-type aluminum cast alloys subjected to artificial aging. Materials Science and Engineering: A. 2008;480(1-2):356-364.
6. Elsebaie O, Mohamed AMA, Samuel AM, Samuel FH, Al-Ahmari AMA. The role of alloying additives and aging treatment on impact behavior of 319 cast alloy. Materials \& Design 2011;32(6):3205-3220.

7. Tibballs JE, Horst JA, Simensen CJ. Precipitation of $\alpha-\mathrm{Al}(\mathrm{Fe}, \mathrm{Mn}) \mathrm{S}$ from the melt. Journal of Materials Science. 2001;36(4):937-941

8. ASM International. ASM Handbook, Volume 02 - Properties and Selection: Nonferrous Alloys and Special-Purpose Materials. Vol 2. $10^{\text {th }}$ ed. Materials Park: ASM International; 1990. p. 148-177.

9. Hernandez-Sandoval J, Garza-Elizondo GH, Samuel AM, Valtiierra $\mathrm{S}$, Samuel FH. The ambient and high temperature deformation behavior of $\mathrm{Al}-\mathrm{Si}-\mathrm{Cu}-\mathrm{Mg}$ alloy with minor $\mathrm{Ti}, \mathrm{Zr}, \mathrm{Ni}$ additions. Materials \& Design. 2014;58:89-101.

10. Mohamed AMA, Samuel FH, Al-kahtani S. Microstructure, tensile properties and fracture behavior of high temperature $\mathrm{Al}-\mathrm{Si}-\mathrm{Mg}-\mathrm{Cu}$ cast alloys. Materials Science and Engineering. A. 2013;577:64-72

11. Hayajneh MT, Hassan AM, Jaradat YM. The Effect of Nickel Addition, Solution Treatment Temperature and Time on the Precipitation Hardening of (Al-Cu) Alloys. Academia.edu. 2007;141:1-5.

12. Hamasha MM, Mayyas AT, Hassan AM, Hayajneh MT. The effect of time, percent of copper and nickel on naturally aged $\mathrm{Al}-\mathrm{Cu}-\mathrm{Ni}$ cast alloys. Journal of Minerals \& Materials Characterization and Engineering. 2012;11(2):117-131.

13. Wessel JK, ed. Handbook of Advanced Materials: Enabling New Designs. Vol. 3. Hoboken: John Wiley \& Sons; 2004. $656 \mathrm{p}$.

14. Moustafa MA, Samuel FH, Doty HW. Effect of solution hea treatment and additives on the hardness, tensile properties and fracture behaviour of Al-Si (A413.1) automotive alloys. Journal of Materials Science. 2003;38(22):4523-4534.

15. Kim KS, Sung SY, Han BS, Jung CY, Lee KA. High temperature high cycle fatigue behavior of new aluminum alloy strengthened by $(\mathrm{Co}, \mathrm{Ni})_{3} \mathrm{Al}_{4}$ particles. Metals and Materials International. 2014;20(2):243-248

16. Xiao DH, Wang JN, Ding DY, Yang HL. Effect of rare earth Ce addition on the microstructure and mechanical properties of an $\mathrm{Al}-\mathrm{Cu}-\mathrm{Mg}-\mathrm{Ag}$ alloy. Journal of Alloys and Compounds. 2003;352(1-2):84-88.

17. Zolotorevsky VS, Belov NA, Glazoff MV. Casting Aluminum Alloys. $1^{\text {st }}$ ed. Oxford: Elsevier; 2007.

18. Samuel AM, Gauthier J, Samuel FH. Microstructural aspects of the dissolution and melting of $\mathrm{Al}_{2} \mathrm{Cu}$ phase in Al-Si alloys during solution heat treatment. Metallurgical and Materials Transactions A. 1996;27(7):1785-1798.

19. Shaha SK, Czerwinski F, Kasprzak W, Friedman J, Chen DL. Thermal stability of (AlSi) $\left.)_{x} \mathrm{ZrVTi}\right)$ intermetallic phases in the $\mathrm{Al}-\mathrm{Si}-\mathrm{Cu}-\mathrm{Mg}$ cast alloy with additions of $\mathrm{Ti}, \mathrm{V}$, and $\mathrm{Zr}$. Thermochimica Acta. 2014;595:11-16.

20. Sokolowski JH, Djurdjevic MB, Kierkus CA, Northwood DO Improvement of 319 aluminum alloy casting durability by high temperature solution treatment. Journal of Materials Processing Technology. 2001;109(1-2):174-180. 
21. Zhu M, Jian Z, Yang G, Zhou Y. Effects of T6 heat treatment on the microstructure, tensile properties, and fracture behavior of the modified A356 alloys. Materials \& Design (1980-2015). 2012;36:243-249.

22. Kashyap KT, Koppad PG. Small-angle scattering from GP zones in Al-Cu alloy. Bulletin of Materials Science. 2011;34(7):1455-1458.

23. Ringer SP, Hono K. Microstructural Evolution and Age Hardening in Aluminum Alloys: Atom Probe Field-Ion Microscopy and Transmission Electron Microscopy Studies. Materials Characterization. 2000;44(1-2):101-131.

24. Soffa WA, Laughlin DE. Diffusional Phase Transformations in the Solid State. In: Laughlin DE, Hono K, eds. Physical Metallurgy. vol. 1. $5^{\text {th }}$ Ed. Oxford: Elsevier; 2014. p. 851-1020.
25. Rioja RJ, Laughlin DE. The early stages of GP zone formation in naturally aged in Al-4 WT pct cu Alloys. Metallurgical Transactions A. 1977;8(8):1257-1261.

26. Wiengmoon A, Pearce JT, Chairuangsri T, Isoda S, Saito H, Kurata H. HRTEM and HAADF-STEM of precipitates at peak ageing of cast A319 aluminium alloy. Micron: The International Research and Review Journal for Microscopy. 2013;45:32-36.

27. Silcock JM, Heal TJ, Hardy HK. Structural ageing characteristics of binary aluminium-copper alloys. Japan Institute of Metals. 1954;82:239-248.

28. Matsubara E, Cohen JB. The G.P. zones in Al-Cu alloys II. Acta Metallurgica. 1985;33(11):1957-1969. 